\title{
Urban quality and the sustainable city in Norway: the challenge of density
}

\author{
F. Hernandez-Palacio \\ Norwegian University of Science and Technology NTNU, \\ Department of Urban Design and Planning, Norway
}

\begin{abstract}
Increasing urban density has been regarded as one of the key strategies to achieve sustainable urban ways of living. The compact city has become the paradigm of the sustainable urban form particularly because of its contribution to environmentally friendly mobility and the decrease of the carbon footprint. Density has also been a precondition to many of the qualities of the 'good city' in the tradition of architecture, urban design, and planning, long before the emergence of the concept of the sustainable city. This former ideal can be closely related to the principles behind the sustainable city, and can be a highly relevant contribution to the materialisation of sustainable built environments. The question addressed in this paper is how density can contribute to the ideal of the 'good city', since this quality is a key component of the Norwegian sustainable city policy. This paper analyses density as a key component of the concept of urban quality through a comprehensive literature review. The findings indicate that urban density was a key component of the ideal of the 'good city' long before the emergence of urban sustainability. Density has been incorporated later as an essential characteristic of the Norwegian sustainable city policy. Increasing density, however, may have two kinds of risk: the first is the decline of urban quality and its consequences in people's quality of life, and the second is the increase of gentrification and the exacerbation of social inequalities.

Keywords: sustainable city, urban density, urban quality, sustainable city policy, compact city, good city, quality of life.
\end{abstract}




\section{Introduction}

Cities are complex systems and defining the urban qualities that foster sustainable societies can be an intricate task. The contemporary city is at the same time the space of economic production, social (human) well-being, and environmental quality. These three aspects, in addition to the issue of governance, have been highlighted as key components of sustainability in the 'Action agenda for sustainable development' of the United Nations [1]. When the object of study is the city, these four dimensions of sustainable development have been frequently addressed in divergent ways. From the economic perspective, cities are regarded as spaces for socio-economic prosperity and innovation [2]; competitiveness has been considered as a central concept in creating the urban qualities that can attract economic and human capital [3]. The societal perspective usually addresses the city as the space of social development and social process [4-6], involving concepts such as equity [7], social justice [8], well-being, and quality of life $[9,10]$. The environmental dimension of the city in the frame of sustainable development has been focused mainly on the question of the demands and the impacts of the city and society on ecosystems in terms of the ecological footprint [11], or environmental quality and public health $[10,12]$.

The multiple fragmentation of aspects of urban life creates difficulties when the aims have to be materialised into concrete interventions and urban projects. While the theory behind the sustainable city must be separated into aspects and dimensions in order to be studied from different perspectives, the physical interventions in the urban space have to be the synthesis of all of them. This is not a minor challenge and it is an intrinsic part of theory and practice in architecture, urban design, and planning. The production of the city as well as its everyday use and its permanent adaptation is not the task of a single profession or a particular social group. Cities are fundamentally a social product. And as societies evolve cities also change. This capacity for adaptation is one of a city's main challenges and it is a key characteristic of both the sustainable city and the good city.

The purpose of this paper is to explore urban density and the associated qualities that have been highlighted as fundamental in the question of the 'good city' in the tradition of architecture and urban design. This exploration comprises two periods: the first is that of the 1960s and 1970s, characterised by strong criticism of modern planning and the functional city approach. The second period sees the emergence of the sustainable city paradigm and its broad influence on the design of sustainable city policies around the world. Subsequently, there is exploration of a number of white papers and policies produced by the Norwegian Government since the early 2000s to synthetise the urban values promoted in the Norwegian city. This exploration is aimed at defining the qualities of the sustainable Norwegian city and determining to what extent they are in tone with the qualities of the good city according to the tradition of architecture, urban design, and planning. The first section of this paper, The Good City in the Tradition of Architecture and Planning, offers a synthesis of the built environment values described in some of the most 
significant texts in the discipline. The second section, Urban Qualities and Sustainable Development, presents a more recent approach to the issue of urban quality following the emergence of the idea of sustainable development. The third section, The Sustainable City in Norway, describes how the sustainable city has been addressed in Norway and how the qualities of the sustainable city are defined according to planning policies. The final section, Conclusions and Recommendations for Further Research, contrasts the findings and proposes directions for future work.

\section{The good city in the tradition of architecture and planning}

The Vitruvian virtues Utilitas, Firmitas, and Venustas (usefulness, solidity, and beauty) have been recognised as the key qualities in architecture and the city since Roman times and have been part of the western tradition since then. Hence, over time there has been more or less emphasis on one of those aspects, or new values have been added. The functional city of the modern movement, for instance, had a greater emphasis on the utilitarian aspect of space, proposing a separation according to four essential functions: living, working, recreation, circulation [13]. However, several opposing voices have emerged in response to the widespread application of the principles of modern urban planning. Thus the debate on the good city gained a central position among theorists and practitioners of the disciplines related to social and built environment issues, particularly in the 1960s and 1970s. Among the most recognised texts on this debate are: The image of the city [14], The death and life of great American cities [15], The city in history [16], A pattern language [17], The reconstruction of the city [18], and Good city form [19]. Table 1 presents a synthesis of the qualities of the good city according to these authors.

Table 1: The good city in the 1960s and 1970s.

\begin{tabular}{|l|l|l|l|l|}
\hline Lynch (1960) & Jacobs (1961) & Mumford (1961) & Alexander (1977) & Lynch (1981) \\
legibility & diversity & significance & diversity & vitality \\
identity & intensity & flexibility & character & sense \\
structure & connectivity & density & accessibility & fit \\
meaning & density & integration & density & accessibility \\
& & meaning & control \\
\hline
\end{tabular}

Lynch devotes attention to the visual quality of the built environment in his book The image of the city [14]. He highlights the scarcity of beautiful urban environments in existing American cities. One of the main qualities of the good city, according to Lynch, is 'legibility', or the clarity of the image that the city offers to its users. The city image is composed of five types of element: path, landmark, edge, node, and district. The quality of the city is defined in terms of the image that it creates in the user, according to the combination and disposition of these elements. 
Jacobs develops a strong criticism of the dominant practices in planning and urban design in The death and life of great American cities [15]. According to her, the principles and aims that have shaped modern, orthodox city planning and rebuilding do not understand how cities operate in real life. For Jacobs [15, pp. 3-25], cities are systems of complex and fine diversity of environments and users that support each other mutually, both socially and economically. The dominant tradition in urban design and planning, according to her, has failed in attaining the diversity that sustains urban vitality. She outlines four primary conditions to urban vitality: (1) diversity of uses in urban districts to keep vitality throughout the day and promote intensive use of existing facilities and public spaces; (2) small blocks to allow connectivity and promote diverse alternatives for pedestrians in attaining a destination; (3) diversity of buildings in ages and styles to allow different uses and diverse users (the diversity of users understood as a mix of people from different social backgrounds, ages, and incomes is a key element of a vibrant urban environment); and (4) urban density as a condition to allow intensity and diversity.

In his seminal work, The city in history [16], Mumford criticises the standardisation of existing cities. He highlights the virtues of the medieval town, particularly its diversity, intimacy, and rich spatial experience produced through a system that combines high density, intricate public space fabric, and controlled openness. However, he does not propose formulations for existing cities. Alexander et al. [17] develop a compendium of patterns in the built environment in their book $A$ pattern language: 253 patterns, from the regional scale to the details of construction, are described. According to these authors, the vitality of the built environment depends on how society as a whole sets and combines different patterns in towns and buildings. Without being an open criticism of the existing paradigm ruling the development of the built environment, this work has the aim of providing the fundamentals for an incremental change of ongoing theories and practices.

In 'The reconstruction of the city', Krier [18] criticises the post-war reconstruction of European cities because of its monotony and its vagueness in defining the public space. He argues that the separation of functions, the dissolution of the urban fabric, and the introduction of large and mono-functional urban blocks have caused the physical and social destruction of cities. He proposes the re-creation of the basis for architecture and urban design as a return to tradition and to the historical city, particularly in the conception of the urban components: the block, the street, the square, and the quartier. Among the principles of the reconstruction of the city are: the conservation of the historical centres as models of collective life; the idea of the public space as organiser of the urban form; and the transformation of mono-functional housing areas into quartiers combining multiple urban functions.

Lynch develops further the principles around urban quality in Good city form [19]. The attributes or dimensions which determine the good city are closely related to a 'good quality of life'. Hence, a good settlement according to Lynch [19, pp. 116-119] 'enhances the continuity of a culture and the survival of its people, increases a sense of connection in time and space, and permits or spurs 
individual growth development, within continuity, via openness and connection ... a good settlement is also an open one: accessible, decentralized, diverse, adaptable, and tolerant to experiment ....'. The good city is determined by five attributes: (1) vitality, understood as the capacity to support the vital functions and biological requirements of human beings; (2) sense, in terms of perception and meaning; (3) fit, in terms of capacity to support the social needs of the community and the capacity to adapt to future demands; (4) accessibility, as the capacity to provide access to enough diverse people, activities, resources, services, information, or places; and (5) control, as the ability to modify and adapt the degree of access, creation, modification, and reparation of elements. Additionally, two meta-criteria are proposed: (6) efficiency, in terms of cost of maintenance and operation of the settlement; and (7) justice, understood as the ability to provide benefits to inhabitants in an equitable way.

\section{Urban qualities and sustainable development}

The concept of sustainable development gains force in the late 1980s and during the 1990s through several reports and conferences of the United Nations on development and environmental issues. The city has been regarded as a key object in sustainable development, as an increasing proportion of human activities happen within urban areas. A particular emphasis in the sustainable city agenda has been put on energy consumption in transportation and everyday travel behaviours. For many authors there is a direct relation between transport and urban form [20-22]. Unlike the previous works, now the question is not how to improve the maladies originating from the modern urban planning approach, but how to generate the urban qualities demanded by the new trend of compact cities, which has become the paradigm of the sustainable city.

A more recent work addressing the issue of urban quality and the good city form within the frame of sustainability is Montgomery [23]. The author presents the concept of 'urbanity', understood as the characteristic of an urban area to favour activity in streets and public space. Urbanity is a precondition for a good city. For Montgomery [23, pp. 96-97], this characteristic requires the combination of three qualities: 'activity (land uses, pedestrian flow, behaviour patterns, noise \& smell, vehicle flow); physical setting (townscape, built form, permeability, landscape, and furniture); and meaning (legibility, cultural associations, perceived functions, attractions, qualitative assessments)'. A description of 12 physical conditions to make a city is presented in Table 2.

Characteristics such as compactness, mixed use, a balanced network of centralities of different hierarchies, and proximity between housing areas, working areas, and urban services are considered key elements of a sustainable urban form. Those formal characteristics, according to Montgomery's recommendations, should be combined with qualities such as variety in the supply of housing (different sizes, ages, styles, and values) in order to promote social diversity, accessibility to a high-quality public transport system, and provision of a well-developed network for non-motorised transport modes (see 
Table 2). Those qualities are, according to Kenworthy [24], considered essential to decrease the use of the car and encourage environmentally friendly mobility such as public transport, cycling, and walking.

Table 2: The good city within the frame of sustainability.

\begin{tabular}{|l|l|}
\hline Montgomery (1998) & Kenworthy (2006) \\
intensity & compact urban form \\
mixed use & rural-urban permeability \\
fine grain & priority of non-car based mobility \\
adaptability & use of clean technologies \\
human scale & balanced accessibility \\
permeability & high-quality public realm \\
visual control & variety of urban environments \\
vitality & dynamic economy \\
movement & inclusive planning \\
green & integral decision making \\
landmarks & \\
architecture & \\
\hline
\end{tabular}

\section{The sustainable city in Norway}

Increasing density and urbanism of proximity are being promoted as the strategies to achieve sustainability targets in urban development. It is expected that the combination of these two strategies can lead cities towards environmentally friendly mobility behaviours, and consequently towards a reduction of greenhouse gases emissions. Examples of this approach in Norway are programmes such as Better environment in cities and towns [25], and Cities of the Future [26].

Table 3: Better environment in cities and towns.

\begin{tabular}{l}
\hline Promotion of regional urban networks between central cities and smaller towns \\
\hline Urban densification and environmentally friendly public transport \\
\hline Integrated land use and transport planning in long-term strategies \\
Strengthening of public transport \\
Improvement of public space networks for pedestrians and cyclists \\
Urban intensification around public transport nodes \\
Promotion of denser housing solutions \\
Adequate location of business and urban services according to public transport \\
Reduction of motorised transport \\
\hline Preservation and development of green and forest areas accessible to urban residents \\
\hline Conservation of historic urban areas and buildings \\
\hline Strengthening of traditional urban centres and neighbourhood centres \\
\hline Varied offer of commerce, cultural activities and services \\
Protection of historic values in buildings and urban quarters \\
Conservation of green areas in the inner city \\
Promotion of good environments for children and youth \\
Incentivisation for accessibility to and safety in public space and outdoor green areas \\
Reduction of noise in residential areas \\
Promotion of denser and alluring urban environments
\end{tabular}


The compact city approach may be regarded as ambitious given the lowdensity landscape that dominates the Norwegian urban areas and the apparent predilection of Norwegian households for detached houses. Norway is also a high-income country where car usage is among the highest in Europe [27]. However, there is empirical evidence that density has been increasing in the largest Norwegian cities, although the advance in environmentally friendly mobility is much less evident [28, 29]. Perhaps it is too early to produce a reliable assessment of this planning approach. Longer-term actions may be required to produce significant urban changes, both formal and functional. Hence the question of increasing urban density seems to be a long-term policy and thus understanding the qualities of a denser city is a key element in the success of the sustainable city agenda.

Table 4: The contemporary sustainable city.

\begin{tabular}{l} 
City of proximity \\
Proximity and accessibility to public transport, shops and local services, kindergarten and schools, meeting space \\
and attractive green spaces within walkable distances \\
\hline High quality \\
High standards of quality, safety, aesthetics, landscape and architecture. Architecture, land use, transport and public \\
spaces should be interconnected concepts in the search of attractiveness to diverse users \\
Coexistence of old and new \\
Densification within the existing boundaries demands reuse of the exiting building stock. Those buildings may need \\
adaptions for current demands. This retrofit should be performed with special care for historic and aesthetic values. \\
Cultural heritage is an essential part of the good urban environment \\
Inclusive cities \\
City space should be adapted to favour the pedestrian and cyclist. Car use should be avoided, particularly for short \\
trips. Pedestrian network and bicycle paths should be designed according to each urban context. Densification and \\
proximity to services is also a key aspect of green mobility \\
The green choice \\
City space should be adapted to favour pedestrian and cyclist. The use of car should be avoided particularly in short \\
trips. Pedestrian networks and cycle paths should be designed according to each urban context. Densification and \\
proximity to services are key aspects of green mobility \\
Healthy, green cities for all \\
Urban space should encourage public health and welfare. The space of the city should promote diverse social \\
activities, sense of belonging and togetherness
\end{tabular}

Many of the values of the good city described above are targeted in several white papers published since 2002 by the Norwegian Ministry of the Environment. Some of these documents establish guidelines and objectives for urban development, for example 'Better environment in cities and towns' [25] (see Table 3) and The contemporary sustainable city [30] (see Table 4). Some others present general environmental objectives and planning instruments from which some guidelines are directed at cities, as is the case of The Government's environmental policy and the state of the environment in Norway [31] and Norway's environmental targets [32]. These papers are consistent in promoting the values of the eco-city at all spatial scales: the neighbourhood, the city, and the region. One of the most relevant examples of this approach is the programme Cities of the future [26] (see Table 5) whose aims are described in Norway's environmental targets [32, p. 32] in the following terms: 'The main objective is to reduce greenhouse gas emissions from road transport, stationary energy use, 
consumption and waste in the largest urban areas. Climate change adaptation strategies are also to be developed. In addition, the programme is intended to provide a better urban environment, which will improve public health, promote commercial activities and make towns more attractive places to live in.'

Table 5: Cities of the future.

The four priority areas of the program Cities of the future

\begin{tabular}{l} 
Land use and transport \\
To reduce the use of cars in the city \\
To strength the traditional city centre and the local centralities \\
To increase the use of collective transport, cycling and walking \\
To decrease the distances to daily urban services (grocery shops, kindergarten, schools, green public spaces) \\
\hline Consumption and waste \\
To improve waste treatment and recycling \\
To decrease the use of disposable packaging \\
To encourage sustainable and durable consumption \\
Energy and buildings \\
To reduce energy consumption \\
To produce energy from sustainable sources \\
To implement heating districts in residential and commercial areas \\
Climate change adaptation \\
To strengthen cities to deal with events associated with climate change (rain, landslides, higher sea level, and wind) \\
\hline
\end{tabular}

\section{Conclusions and recommendations for further work}

The sustainable city is still a very imprecise object, built on aims rather than on facts. There is a strong correlation between the qualities of the good city and the targets of sustainable city policies. However, the renewal of the existing city according to these principles is still incipient. This is particularly evident in the materialisation of sustainable principles in concrete urban projects. Qualities such as intensity and vitality are difficult to achieve by mere normative instruments. The principles of sustainable development and the theories behind them are useful in decision making and in the elaboration of planning documents, building regulations and other non-spatial issues. But these theoretical paradigms seem to be poorly materialised into urban form and urban quality when applied in concrete urban interventions.

The increase of urban density has been one of the recommended measures despite controversy. On the one hand, there may be possible implications in urban quality decline and social acceptability problems. And on the other hand, there may be gentrification problems. Therefore, if urban density does not incorporate simultaneously other urban qualities to improve the urban environment all over the city, this could imply the failure in the implementation of sustainable city policies, whether by poor social acceptability or by exacerbated gentrification. Urban quality is thus a particularly relevant issue in contexts such as the Norwegian, where there has been a tradition of low urban 
density and the population has the means to afford the economic cost of sprawled urban environments.

The sustainable city in Norway has been approached with a great emphasis on environmental aspects. One of the main purposes has been the decrease of dependence on private cars, which is considered as an important step in achieving a low carbon society. Thus, the ideal means of urban mobility are public transport, walking, and cycling. The urban form has to adapt to these 'new' mobility conditions by increasing density and promoting the proximity to work and everyday urban services, so that they can be accessed without need of car usage. There have been noticeable increases in urban density, particularly in Oslo [28]. But the risks of higher densities are of two kinds: urban decline and gentrification. The first happens when density increases are not accompanied by other physical improvements and such areas lose attractiveness. The second occurs when urban upgrading actions are concentrated in a few parts of the city while others are neglected. In consequence, the low-income population is expelled from the improved areas towards the neglected ones because of the increase in property values.

A research agenda on this theme should answer questions related to these two possible outcomes, urban decline and gentrification. Questions about the right proportion between density, availability of public space, and non-residential uses should be studied carefully in successful urban areas. Other questions such as how much density is accepted or which urban typologies are suitable for a determined context are also very relevant in the materialisation of the sustainable city. Policies, regulations, and new projects should learn about the qualities of such environments. Also, urban quality in relation to quality of life is a critical subject that requires additional research. Urban quality, despite some universal values, has many local components that require specific research. The social impacts of urban upgrading must be understood in very specific contexts to be tackled adequately. How gentrification is happening in Norwegian cities and which actions can be effective in such a context have to be another question on this research agenda. The tackling of gentrification should incorporate a range of action, spatial and non-spatial. The spatial perspective should address a balanced distribution of urban quality in the whole city. The social and economic aspect of gentrification should be managed via policies, subsidies, and protected housing for vulnerable communities.

\section{Acknowledgements}

Special thanks are due to the author's supervisors, Dag Kittang and Eli Støa, and to Fernanda Pacheco, my colleague, for reading the text and providing valuable recommendations for development. This paper is written as part of the $\mathrm{PhD}$ research 'City reconstruction and densification' funded by the Department of Urban Design and Planning of the Norwegian University of Science and Technology (NTNU). The author is also funded by a grant from the Colombian Administrative Department of Science, Technology and Innovation (COLCIENCIAS). 


\section{References}

[1] SDSN - Sustainable Development Solutions Network. 2013. An Action Agenda for Sustainable Development. In: (SDSN), T. S. D. S. N. (ed.). United Nations.

[2] Nijkamp, P. \& Kourtit, K. 2013. The "New Urban Europe": Global Challenges and Local Responses in the Urban Century. European Planning Studies, 21, 291-315.

[3] Rogerson, R. J. 1999. Quality of life and city competitiveness. Urban Studies, 36, 969-985.

[4] Castells, M. 1972. La question urbaine, Paris, François Maspero.

[5] Lefebvre, H. \& Nicholson-Smith, D. 1991. The production of space, Blackwell Oxford.

[6] Harvey, D. 2003. The right to the city. International Journal of Urban and Regional Research, 27, 939-941.

[7] Troy, P. N. 2012. Equity in the City, Routledge.

[8] Harvey, D. 2010. Social justice and the city, University of Georgia Press.

[9] Pacione, M. 2003. Urban environmental quality and human wellbeing-a social geographical perspective. Landscape and Urban Planning, 65, 1930.

[10] Van Kamp, I., Leidelmeijer, K., Marsman, G. \& De Hollander, A. 2003. Urban environmental quality and human well-being: Towards a conceptual framework and demarcation of concepts; a literature study. Landscape and Urban Planning, 65, 5-18.

[11] Wackernagel, M., Kitzes, J., Moran, D., Goldfinger, S. \& Thomas, M. 2006. The ecological footprint of cities and regions: comparing resource availability with resource demand. Environment and urbanization, 18, $103-112$.

[12] Frank, L. D. \& Engelke, P. O. 2001. The built environment and human activity patterns: exploring the impacts of urban form on public health. Journal of Planning Literature, 16, 202-218.

[13] Iamandi, C. 1997. The Charters of Athens of 1931 and 1933: Coincidence, controversy and convergence. Conservation and Management of Archaeological Sites, 2, 17-28.

[14] Lynch, K. 1960. The image of the city, MIT press.

[15] Jacobs, J. 1961. The death and life of great American cities, Random House LLC.

[16] Mumford, L. 1961. The city in history: its origins, its transformations, and its prospects, New York, Harcourt.

[17] Alexander, C., Ishikawa, S. \& Silverstein, M. 1977. A pattern language: towns, buildings, construction, Oxford University Press, USA.

[18] Krier, L. 1978. The Reconstruction of the City. Rational Architecture: The Reconstruction of the City Brussels Archives d'Architecture Moderne.

[19] Lynch, K. 1981. Good city form, The MIT Press.

[20] Newman, P. W. \& Kenworthy, J. R. 1996. The land use-transport connection: An overview. Land Use Policy, 13, 1-22. 
[21] Jabareen, Y. R. 2006. Sustainable Urban Forms: Their Typologies, Models, and Concepts. Journal of Planning Education and Research, 26, 38-52.

[22] Næss, P. 2012. Urban form and travel behavior: Experience from a Nordic context. Journal of Transport and Land Use, 5, 21-45.

[23] Montgomery, J. 1998. Making a city: urbanity, vitality and urban design. Journal of Urban Design, 3, 93-116.

[24] Kenworthy, J. R. 2006. The eco-city: ten key transport and planning dimensions for sustainable city development. Environment and urbanization, 18, 67-85.

[25] Norwegian Ministry of the Environment. 2002. Bedre miljø i byer og tettsteder (Online). Oslo: Miljøverndepartementet. Available: http://www.regjeringen.no/nb/dep/md/dok/regpubl/stmeld/20012002/stmel d-nr-23-2001-2002-.html?id=196048 (Accessed 2910 2013).

[26] Norwegian Ministry of the Environment. 2008. Cities of the Future (Online). Oslo: Miljøverndepartementet. Available:

http://www.regjeringen.no/en/sub/framtidensbyer/cities-of-the-future.html ?id=548028 (Accessed 1203 2013).

[27] Brunvoll, F. \& Monsrud, J. 2013. Samferdsel og miljø 2013: Utvalgte indikatorer for samferdselssektoren. Statistisk sentralbyrå. Oslo.

[28] Næss, P., Næss, T. \& Strand, A. 2011. Oslo's farewell to urban sprawl. European Planning Studies, 19, 113-139.

[29] Haagensen, T. 2012. Byer og miljø: Indikatorer for miljøutviklingen i "Framtidens byer", Oslo, Statistisk sentralbyrå.

[30] Norwegian Ministry of the Environment. 2013. Den Moderne Bærekraftige Byen Oslo: Miljøverndepartementet.

[31] Norwegian Ministry of the Environment. 2007. The Government's Environmental Policy and the State of the Environment in Norway. Department of Information Management ed. Oslo.

[32] Norwegian Ministry of the Environment. 2012. Norway's Environmental Targets. Oslo: Norwegian Ministry of the Environment. 